\title{
The impact of social commerce on online purchase intention: The mediation role of trust in social network sites
}

\author{
Abdalrazzaq Aloqool ${ }^{\mathrm{a} *}$ and Mohammad A.K Alsmairat ${ }^{\mathrm{b}}$
}

${ }^{a}$ Marketing Department, Faculty of Business, Applied Science University, Jordan

${ }^{b}$ Assistant professor in supply chain management, Luminus Technical University College, Jordan

\section{H R O N I C L E \\ A B S T R A C T}

Article history:

Received: July 22, 2021

Received in revised format: Sep-

tember 16, 2021

Accepted: December 8, 2021

Available online: December 8,

2021

Keywords:

Social commerce

Trust

SNS

Online Purchase Intention
This research aimed to investigate the impact of social commerce on online purchase intention. The mediation role of trust in social network sites between social commerce and online purchase intention was explored. Dataset obtained from 467 Jordanian users of social network sites. PLS-SEM was conducted for analysis purposes. The findings reveal that social commerce and trust in social network sites directly affect online purchase intention. The findings have additionally shown that trust in social network sites has a mediating role between social commerce and online purchase intention. The main recommendation to companies is to derive significant benefits from social commerce and consider them to maximize the potential level of online purchases. Suggestions for further studies are mentioned at the end of the study.

\section{Introduction}

Social media has become the new era of communication around the world. Recent statistics show that 3.81 billion individuals in the world are active social media users (Statista, 2020). Social media has different forms, such as virtual communities, web blogs, micro blogs, wikis, pictures and video sharing, and social network sites (Xiang \& Gretzel, 2010; Amato et al., 2019; Koukaras et al., 2020; Lovari \& Valentini, 2020). Social network sites (SNS) are now the most popular and influencing platforms in people's daily lives (Xu et al., 2012, del Fresno Garcia et al., 2017; Hellemans et al., 2020). SNS such as Facebook, Instagram, and YouTube have interactive features by employing Web 2.0 which allows for two-way communications between all users (Kietzmann et al., 2011; Berger et al., 2014; Hellemans et al., 2020; Al-Gasawneh et al., 2020). Businesses and people recently started to use SNS in commerce activities such as marketing, buying and selling (Zhou \& Zimmermann, 2013; Nusairat et al., 2021). These activities are now called Social Commerce (SC) which pinpoints to business and people interactive involvement in commerce and creating content on SNS (Shin, 2013; Hajli, 2014; Chae et al., 2015; Lin et al., 2017). Fisher (2010) considered the components that shape SC are rates and reviews, recommendation and referrals, forums and community social advertising and social shopping, but Hajli (2015) theorize only the first three; rates and reviews, recommendation and referrals, forums, and community, and called them Social Commerce Construct (SCC).

Customers have an influencing role over other customers by sharing their information and experiences (Chae et al., 2015). The role customers play is seen as recommendations to other customers, reviews about products or services, ratings that customers assign to different products, and customers' comments and opinions left in different forums or communities (Hajli,

* Corresponding author.

E-mail address: a a aloqool@asu.edu.jo (A. Aloqool)

(C) 2022 by the authors; licensee Growing Science, Canada. doi: $10.5267 /$ j.ijdns.2021.12.003 
2015b; Wang et al., 2016). This interaction between customers on SNS might lead to affecting others' manners and buying decisions ( $\mathrm{Li}, 2017)$.

As social interaction exists in cyberspace between unknown people; trust matters more. In online markets, trust is a major factor in the form of perceived risk (Gefen et al, 2003). Shin (2010) clarified that trust plays a key role in behavioral intention. Trust leads to customers' intention to buy from online stores (Xu-Priour et al., 2014; Hajli et al., 2017; Li, 2017).

There are few studies conducted about e-marketing in Jordan (Yaseen et al., 2016) and even fewer studies about SC and its adoption (Al-dwairi, 2017). Shdaifat et al. (2016) studied the adoption of SC (specifically Facebook) from a vendors' viewpoint. Al-dwairi (2017) and Momani et al. (2018) explored SC adoption between Jordanian customers. While Alalwan et al., (2019) tried to figure out the relations between SC and customer value creation with a mediating role for social trust, Aladwan and Kokash (2019) examined the behavioral intentions of Jordanian customers to adopt SC through an SNS platform; namely, Facebook. On the contrary, this study considers the effect of Social Commerce Construct (SCC) on trust in SNS and online purchase intention. The study was broadening to all SNSs used by online customers which was recommended by Aladwan and Kokash (2019), also this is like the study of Hammouri et al. (2021). Meanwhile, studies of (Shdaifat et al., 2016; Momani et al., 2018; Alalwan et al., 2019; Al-adwan \& Kokash 2019) specifically were applied on Facebook. Therefore, the study is attempting to investigate if social interaction between consumers over SNS will affect their trust in SNS, and to investigate if trust in SNS affects their intention toward online purchasing. Finally, the study adopts the model proposed by Hajli (2015), which was adopted by Shanmugam et al., (2016) and Ashoer et al. (2021), nevertheless, it is the first time to be adopted in Jordan.

\section{Literature review and Hypotheses Development}

\subsection{Social Commerce}

SC is a new wave of internet marketing (Hammouri et al., 2021). In simple words, it is the application and implementation of word-of-mouth in internet commerce (Jascanu, Jascuna, \& Nicolau, 2007). Stephen and Toubia (2010) defined SC as "a subset of e-commerce and relation-based business." Wang et.al (2012), see SC as motivating consumers to spread their concern and restructuring their purchase decision impartially. Huang and Benyoucef (2015) define it as customers' participation in buyingselling activities over social media platforms by implementing the Web 2.0 technology. SC has been studied from different viewpoints: Fisher (2010) segmented SC into six categories: social media, social advertising, recommendations and referrals, forums and communities, social shopping, ratings, and reviews. Wang and Zhang (2012) described four essential dimensions for SC: people, management, technology, and information. According to Shen (2012); consumers' online shopping behavior consists of three elements: transactional, informational, and social. Zhou et al. (2013) discussed four main components of SC: business, people, technology, and platforms.

\subsection{Social Commerce Construct}

Hajli was developing studies on social commerce deeply until he proposed the SC adoption model in 2013. The model grabs the recommendations and referrals, rating and reviews, forums and communities grouped as Social Commerce Constructs (SCC) with its effect on trust and intention to buy, in addition to the effect of trust and perceived usefulness on intention to buy. Another trial in evaluating SC model was by exploring the effect of SCC on trust only. Hajli (2015) focused on the influence of SC on trust and consumers' intention to buy. The model incorporated SCC, trust, and intention to buy from SNS. The impact of customers' reviews and ratings has a bad impact on business performance (De Pelsmacker et al., 2018). Kaushik et al. (2018) and Forman et al. (2008) concluded that the information in the online reviews is integrated with increased online product sales, however, negative reviews harm the online product sales more than positive ones (Basuroy et al., 2003). Consumers looking for more information to buy online as lack of tangibility is the main barrier in online purchases (Kripesh et al., 2020). Recommendation and referrals, the second part of SCC, are trustworthy sources for information. Clearly, online recommendations and referrals affect the brand selection process (Quinton \& Harridge-March, 2010). Consumer's recommendation can be positively associated with the long tail of demand, where less popular products represent a larger fraction of total sales (Oestreicher-Singer \& Sundararajan, 2012).

The third variable of SCC is forums and communities. Chen et.al (2011) concluded that online communication is the fundamental utility for individuals to engage in exchanging information and knowledge. Lu, Zhao, and Wang (2010) found that these social interactions cultivate consumers with more knowledge that enhances their trust to buy. Furthermore, Hajli (2014) concluded that online communities and forums are the best component of SCC to develop new products and can be an excellent funnel to generate new ideas and modifications for the products, thus communities and forums can remodel the business marketing strategy. Therefore, the researchers propose the hypothesis:

$\mathbf{H}_{1}$ : Social commerce construct has a significant impact on trust in SNS. 


\subsection{Trust in SNS}

Mayer et al. (1995) defined Trust as "the willingness of a party to become vulnerable to the actions of another party based on the expectation that another party will perform a particular action impact to the trustor, irrespective of the ability to monitor or control that other party". Recently, consumers' engagement in social networks improves relations between people and spreads information which has enhanced the level of trust (Lu et al., 2016). From the perspective of SNS, trust is backed by security issues which are still an obstacle to buying from SNS (Cha, 2013). Nick (2015) assured that trust performs a pivotal role in SC, without any doubt; trust is a compulsory variable to study and investigate in SC (Hammouri et al., 2021). Rosa et al., (2018) found that SC has an impact on consumer trust. On the other hand, trust plays a dynamic role in shaping the consumer buying decision process (McKnight et al., 2002; Yoon, 2002, Zalloum et al., 2021). Han and Windsor (2011) found that trust affects users to buy in SNS. Also, trust may have a moderation effect on the risk in the purchasing (Lee et al., 2011). Therefore, the researchers propose the hypothesis:

\section{H2: Trust in SNS has a significant impact on online purchase intention.}

\subsection{Online Purchase Intention}

Online purchasing transactions can be considered as a major daily activity on the internet. Online purchase intention is the situation when a customer is willing and intends to become involved in online purchasing (Pavlou, 2003). Purchase intention has been used as an indicator to expect customers' real engagement in actual buying. (Ariffin et al., 2018). Moreover, Shin (2013) concluded that the intention to buy is clarified by the user when SCC is used, which leads to real behavior to buy on it. Accordingly, the researchers propose the hypotheses:

$\mathbf{H}_{3}$ : Social commerce construct has a significant impact on online purchase intention.

H4: Trust mediates the relationship between social commerce construct and online purchase intention.

\subsection{Research model}

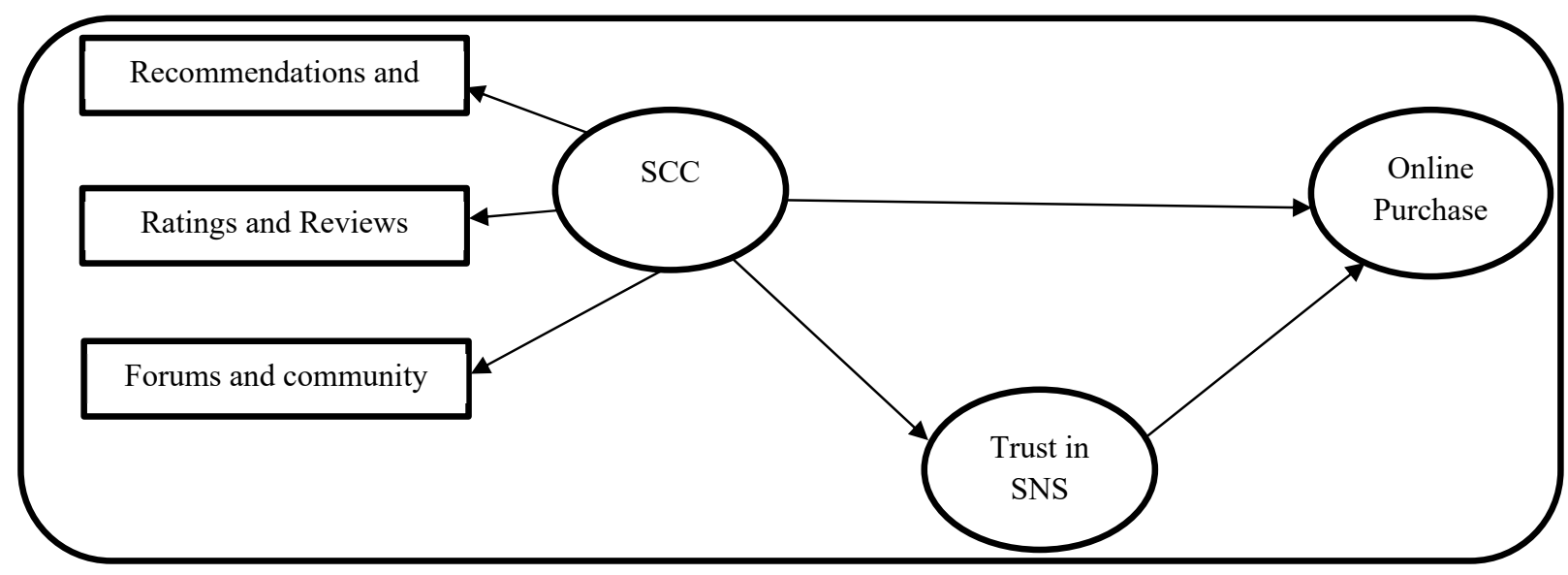

Fig. 1. Research Model

\section{Research Methodology}

This study aims to investigate the behavior of SNS users toward online purchasing. Therefore, the sample should be using the internet for social interaction through SNS and for online shopping. Accordingly, the sample was selected by choosing people who were users of social network sites such as Facebook, Snapchat or Instagram, etc. then, participants were randomly selected from the previous selected pool according to the determined criterion. Consequently, a total number of 480 questionnaires were collected, while 467 questionnaires were eligible to be analyzed. Data was collected through a questionnaire dropped via electronic channels. The questionnaire consists of two sections: the first section is about demographics such as (age, gender, income level), while the second section is about the independent, mediator, and dependent variables represented by 21 items. The items were either adopted, adapted, or utilized, and they are divided into four items measuring each of (recommendation and referrals, ratings and reviews, and forums and communities) constituting the independent variable (SCC) (Han \& Windsor 2011; Liang et al., 2011; Hajli, 2015; Hajli \& Sims, 2015; Maia et al., 2018), five items to measure trust (Gefen et al., 2003; Liang et al., 2011), and four items for the dependent variable; online purchase intention (Kim, \& Park, 2013; Ng, 2013; Celik, 2016; Escobar-Rodríguez \& Bonsón-Fernández, 2017). 
A five-point Likert scale through a structured questionnaire was applied where respondents judged different statements about independent, mediated, and dependent variables. Structural equation modeling by using SmartPLS 3 was conducted. Following (Sarstedt et al., 2016; Hair et al., 2013; Alsmairat \& Aldakhil, 2021) recommendations, PLS-SEM considered a composite structure and mediation relationship.

\section{Results}

Scale validity and reliability were conducted to validate all research variables simultaneously. All measures and all fit indices indicate the good convergent validity of the constructs (Hair et al., 2017). The research constructs also indicated high reliability, as shown by the result of composite reliability, which exceeds 0.70 . According to (Hair et al., 2021), a CR of 0.60 to 0.70 is acceptable. The values of average variance extracted (AVE) were above 0.5 which supports the constructs' discriminant validity. Additionally, Cronbach's alpha values were also above 0.7 , which indicates a high reliability level (Sekaran and Bougie, 2019). Table 1 summarizes these results.

Table 1

Scale validity and reliability

\begin{tabular}{lcc}
\multicolumn{1}{c}{ Constructs } & Alpha Cronbach's & Composite Reliability (CR) \\
\hline Recommendations and Referrals & 0.800 & 0.870 \\
Ratings and Reviews & 0.821 & 0.882 \\
Forums and community & 0.781 & 0.628 \\
Trust & 0.798 & 0.652 \\
Online Purchase intention & 0.926 & 0.608 \\
\hline
\end{tabular}

Having confirmed the five variables, we made the compound values for variables. The result reveals that the kurtosis and skewness test values are within accepted ranges $(<7, \pm 1)$, respectively, which indicates no violation of normality. Furthermore, Pearson bivariate correlations were conducted among all constructs, and the results confirm no concerns for multicollinearity among the variables. Table 2 and figure 2 . summarizes these results.

Table 2

The results of the correlation matrix

\begin{tabular}{lllrr}
\hline Constructs & RR & RV & FC & \\
\hline Recommendations \& Referrals (RR) & 0.792 & & & \\
Ratings \& Reviews (RV) & 0.693 & 0.808 & & \\
Forums \& community (FC) & 0.607 & 0.737 & 0.780 \\
Trust (T) & 0.408 & 0.493 & 0.478 & 0.744 \\
Online Purchase intention (PI) & 0.456 & 0.478 & 0.414 \\
\hline
\end{tabular}

Table 3

The results of path analysis

\begin{tabular}{|c|c|c|c|c|}
\hline Path & $\beta$ & $\mathrm{t}$ - value & $\mathrm{P}$ value & Results \\
\hline Social commerce construct $\rightarrow$ Trust & 0.519 & 14.926 & 0.000 & H1 Accepted \\
\hline Trust $\rightarrow$ Online Purchase intention & 0.230 & 4.780 & 0.000 & H2 Accepted \\
\hline Social commerce construct $\rightarrow$ Online Purchase intention & 0.390 & 6.949 & 0.000 & H3 Accepted \\
\hline Social commerce construct $\rightarrow$ Trust $\rightarrow$ Online Purchase intention & 0.119 & 4.742 & 0.000 & H4 Accepted \\
\hline
\end{tabular}

\section{Discussion and Conclusion}

Social commerce can be considered a new trend utilizing SNS in order to affect marketing activities and direct efforts toward maximizing customers' online purchase intention and to raise the level of usage through embracing trust issues. This paper investigated how and under what circumstances online purchase intention is affected by social commerce and trust in social network sites. The following paragraphs will discuss the main research findings. The first hypothesis's results shown in Table 3 , figure 2 reveal that SCC directly impacts trust in social network sites. This result makes sense, as it has appeared increasingly significant and challenging for companies to gain customers' trust to buy online. A prior empirical study of Hajli (2014) found that the component of SCC is affecting customers' trust as people are trustworthy in their recommendations, ratings, and their reviews. This result complies with and assures Hajli's results and goes in line with it. Furthermore, the result of hypothesis 2 shown in Table 3 and Fig. 2 shows trust in SNS affecting online purchase intention. This confirms that trust has always been a milestone in customers' determinants toward online purchases. This result goes in line with prior scholars' results of Escobar-Rodríguez et al. (2017) and Hammouri et al. (2021) who pointed out that trust in SNS is positively affecting online purchase intention from e-retailers. Hypothesis 3 predicted that SCC directly impacts online purchase intention. The results shown in Table 3, figure2 support this hypothesis. This outcome affirms Hajli's (2016) results, who stated that SCC with its three components is affecting consumer behavior. Regarding this result, we can conclude that companies are capable of achieving more sales through online portals. In addition, firms must emphasize the benefits gained from social interaction over SNS. Hypothesis 4 proposed that trust in SNS has a mediating role between SCC and online purchase intention. The results shown 
in Table 3 and Fig. 2 confirm and support this hypothesis. Previous literature did not examine this relationship empirically but proposed that there is an underlying direct relationship among these variables. This hypothesis can be a new extension to Hajli's (2016) adopted model in this study.

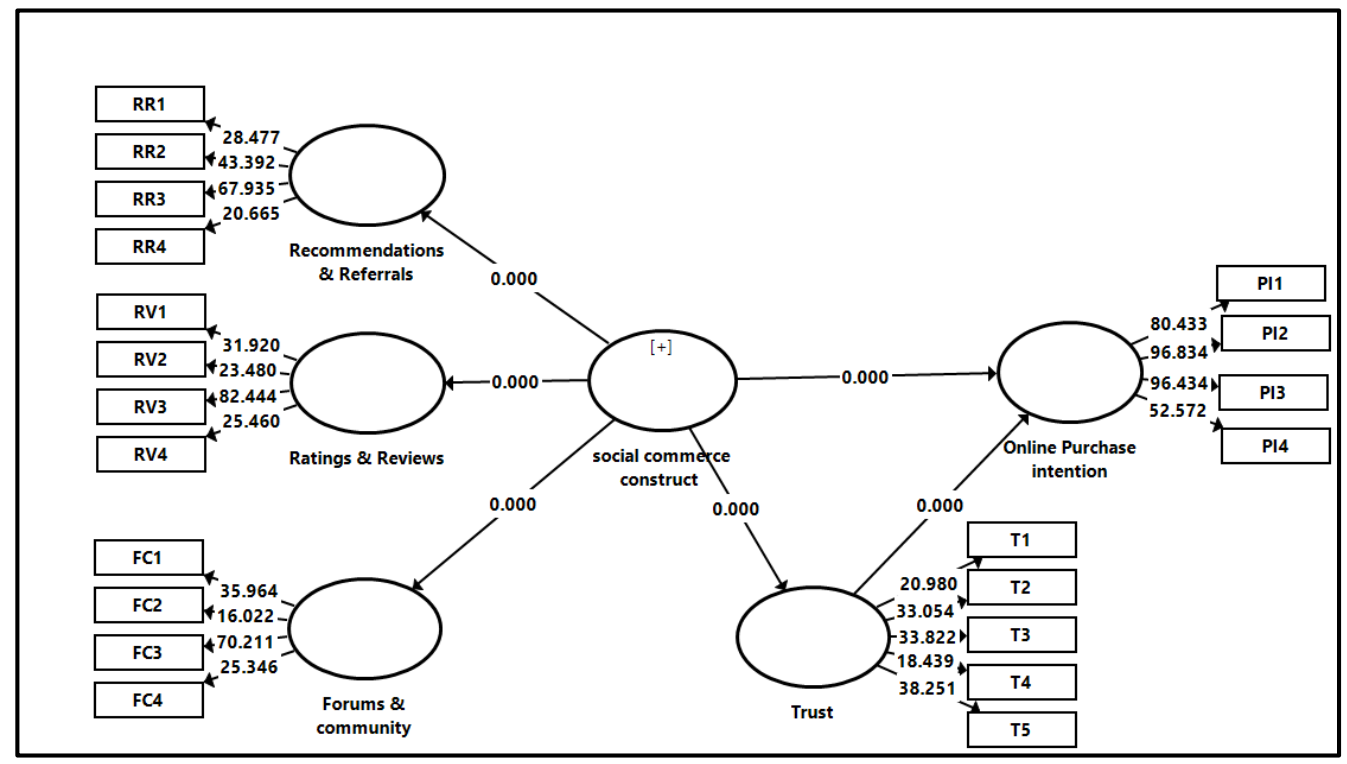

Fig. 2. Path Analysis Results

\section{Implication}

Social Commerce is the upcoming face of online markets by comprising social interaction between users which leads to affect behavior. This research tries to shed light about the effect of SNS on businesses by showing the factors that might influence consumer behavior, therefore companies must give more attention to these SNS with their interactions and outcomes. Consumers' recommendations, ratings, reviews, and general opinions on SNS are highly influencing others' intention to buy. Companies are highly recommended to utilize the presence of their accounts on SNS to monitor people's activities over there. Despite the huge booming of using technology in business, trust is still shaping the bridge that customers cross to the safe side of online purchases. Customers' trust in SNS is built from the influence of social commerce, though, companies should give a priority to build, develop, and continually enhance trust to encourage customers to make purchases through these websites or the internet generally.

\section{Further Research}

This research has some limitations, sampling of the research is recommended to be specialized with actual purchasers from SNS. Moreover, the study didn't apply the research on any industry, so further research may consider any industry and apply the research for it. New potential moderators such as enjoyment might be proposed in the relationship between SCC and purchase intention.

\section{References}

Al-Adwan, A. S., \& Kokash, H. (2019). The driving forces of Facebook social commerce. Journal of Theoretical and Applied Electronic Commerce Research, 14(2), 15-32.

Al-Gasawneh, J., Al-Wadi, M., Al-Wadi, B., Alown, B., \& Nuseirat, N. (2020). The Interaction Effect of Comprehensiveness Between Social Media and Online Purchasing Intention in Jordanian Pharmacies. International Journal of Interactive Mobile Technologies.

Alalwan, A. A., Algharabat, R. S., Baabdullah, A. M., Rana, N. P., Raman, R., Dwivedi, R., \& Aljafari, A. (2019). Examining the impact of social commerce dimensions on customers' value cocreation: The mediating effect of social trust. Journal of Consumer Behaviour, 18(6), 431-446.

Al-Dwairi, R. (2017). Social commerce adoption among Jordanian youth: empirical study. International Journal of Business Information Systems, 26(3), 277-296.

Alsmairat, M., \& Aldakhil, A. (2022). Modeling the interrelationships among environmental forces, organizational capabilities and supply chain sustainability. Uncertain Supply Chain Management, 10(1), 117-124.

Amato, F., Moscato, V., Picariello, A., \& Piccialli, F. (2019). SOS: A multimedia recommender System for Online Social networks. Future Generation Computer Systems, 93, 914-923. 
Ariffin, S. K., Mohan, T., \& Goh, Y. N. (2018). Influence of consumers' perceived risk on consumers' online purchase intention. Journal of Research in Interactive Marketing, 12(3), 309-327.

Ashoer, M., Murdifin, I., Basalamah, J., As'ad, A., \& Pramukti, A. (2021, February). Integrating Social Commerce Constructs into Mobile Application Service; A Structural Equation Model. In Journal of Physics: Conference Series (Vol. 1783 , No. 1, p. 012043). IOP Publishing.

Berger, K., Klier, J., Klier, M., \& Probst, F. (2014). A Review of Information Systems Research on Online Social Networks. CAIS, 35,8 .

Celik, H. (2016). Customer online shopping anxiety within the Unified Theory of Acceptance and Use Technology (UTAUT) framework. Asia Pacific Journal of Marketing and Logistics, 28(2).

Chae, H., Ko, E., \& Han, J. (2015). How do customers' SNS participation activities impact on customer equity drivers and customer loyalty? Focus on the SNS services of a global SPA brand. Journal of Global Scholars of Marketing Science, 25(2), 122-141.

De Pelsmacker, P., Van Tilburg, S., \& Holthof, C. (2018). Digital marketing strategies, online reviews and hotel performance. International Journal of Hospitality Management, 72, 47-55.

del Fresno Garcia, M., Daly, A. J., \& Segado Sanchez-Cabezudo, S. (2016). Identifying the new Influences in the Internet Era: Social Media and Social Network Analysis. Revista Española de Investigaciones Sociológicas, 153.

Escobar-Rodríguez, T., \& Bonsón-Fernández, R. (2017). Analyzing online purchase intention in Spain: fashion e-commerce. Information Systems and e-Business Management, 15(3), 599-622.

Fisher, S. (2010). Social Commerce Camp - Killer Social Commerce Experience. [Online] Available at: http:/www.slideshare.net/stevenfisher/social-commerce-camp-killer-social-commerce-experience/ [Accessed 20 September 2015].

Gefen, D., Karahanna, E. \& Straub, D. W., (2003). Trust and TAM in online shopping: An integrated model. MIS Quarterly, 27(1), 51-90.

Hair Jr, J. F., Hult, G. T. M., Ringle, C. M., \& Sarstedt, M. (2021). A primer on partial least squares structural equation modeling (PLS-SEM). Sage publications.

Hair, J. F., Ringle, C. M., \& Sarstedt, M. (2013). Partial least squares structural equation modeling: Rigorous applications, better results and higher acceptance. Long range planning, 46(1-2), 1-12.

Hair, J., Hollingsworth, C. L., Randolph, A. B., \& Chong, A. Y. L. (2017). An updated and expanded assessment of PLSSEM in information systems research. Industrial Management \& Data Systems, 117(3), 442-458.

Hajli, N. (2014). The role of social support on relationship quality and social commerce. Technological Forecasting and Social Change, 87, 17-27.

Hajli, N. (2015). Social commerce constructs and consumer's intention to buy. International Journal of Information Management, 35(2), 183-191.

Hajli, N. (2015b). Handbook of research on integrating social media into strategic marketing. IGI Global.

Hajli, N., \& Sims, J. (2015). Social commerce: The transfer of power from sellers to buyers. Technological Forecasting and Social Change, 94, 350-358.

Hajli, N., Sims, J., Zadeh, A. H., \& Richard, M. O. (2017). A social commerce investigation of the role of trust in a social networking site on purchase intentions. Journal of Business Research, 71, 133-141.

Hammouri, Q., Al-Gasawneh, J. A., Nusairat, N. M., Hanandeh, A., \& Barakat, S. (2021). The Determinants of Trust and its Influence on Online Buying Intention: An Empirical Study on Social Commerce in Jordan. Annals of the Romanian Society for Cell Biology, 4522-4539.

Hellemans, J., Willems, K., \& Brengman, M. (2020). Daily Active Users of Social Network Sites: Facebook, Twitter, and Instagram-Use Compared to General Social Network Site Use. In Advances in Digital Marketing and eCommerce (pp. 194-202). Springer, Cham.

Huang, Z., \& Benyoucef, M. (2015). User preferences of social features on social commerce websites: An empirical study. Technological Forecasting and Social Change, 95, 57-72.

Kaushik, K., Mishra, R., Rana, N. P., \& Dwivedi, Y. K. (2018). Exploring reviews and review sequences on e-commerce platform: A study of helpful reviews on Amazon. in. Journal of retailing and Consumer Services, 45, 21-32.

Kietzmann, J. H., Hermkens, K., McCarthy, I. P., \& Silvestre, B. S. (2011). Social media? Get serious! Understanding the functional building blocks of social media. Business Horizons, 54(3), 241-251.

Kim, S., \& Park, H. (2013). Effects of various characteristics of social commerce (s-commerce) on consumers' trust and trust performance. International Journal of Information Management, 33(2), 318-332. http://dx.doi.org/ 10.1016/j.ijinfomgt.2012.11.006

Koukaras, P., Tjortjis, C., \& Rousidis, D. (2020). Social Media Types: introducing a data driven taxonomy. Computing, 102(1), 295-340.

Kripesh, A. S., Prabhu, H. M., \& Sriram, K. V. (2020). An empirical study on the effect of product information and perceived usefulness on purchase intention during online shopping in India. International Journal of Business Innovation and Research, 21(4), 509-522.

Lee, J., Park, D. H., \& Han, I. (2011). The different effects of online consumer reviews on consumers' purchase intentions depending on trust in online shopping malls. Internet Research, 21(2), 187-206.

Li, C. Y. (2019). How social commerce constructs influence customers' social shopping intention? An empirical study of a social commerce website. Technological Forecasting and Social Change, 144, 282-294. 
Liang, T. P., Ho, Y. T., Li, Y. W., \& Turban, E. (2011). What drives social commerce: The role of social support and relationship quality. International Journal of Electronic Commerce, 16(2), 69-90.

Lin, X., Li, Y., \& Wang, X. (2017). Social commerce research: Definition, research themes and the trends. International Journal of Information Management, 37(3), 190-201.

Lovari, A., \& Valentini, C. (2020). Public Sector Communication and Social Media. Opportunities and Limits of Current Policies, Activities, and Practices. Handbook of Public Sector Communication.

Lu, B., Fan, W., \& Zhou, M. (2016). Social presence, trust, and social commerce purchase intention: An empirical research. Computers in Human Behavior, 56, 225-237.

Maia, C., Lunardi, G., Longaray, A., \& Munhoz, P. (2018). Factors and characteristics that influence consumers' participation in social commerce. Revista de Gestão.

Momani, A. M., Jamous, M. M., \& Yafooz, W. M. (2018). The influence of enjoyment factor toward the acceptance of social commerce. International Journal of E-Business Research, 14(2), 76-86.

$\mathrm{Ng}$, C. S. P. (2013). Intention to purchase on social commerce websites across cultures: A cross-regional study. Information \& Management, 50(8), 609-620.

Nusairat, N., Abdellatif, H., Al-Gasawneh, J., Akhorshaideh, A., Aloqool, A., Rabah, S., \& Ahmad, A. (2021). Determinants of behavioral intentions to use mobile healthcare applications in Jordan. International Journal of Data and Network Science, 5(4), 547-556.

Pavlou, P. A. (2003). Consumer acceptance of electronic commerce: Integrating trust and risk with the technology acceptance model. International Journal of Electronic Commerce, 7(3), 101-134.

Rosa, R. P., Qomariah, N., \& Tyas, W. M. (2018). Impact of social commerce characteristics on consumer trust on online shop in Instagram. Prosiding CELSciTech, 3, 80-88.

Sarstedt, M., Hair, J. F., Ringle, C. M., Thiele, K. O., \& Gudergan, S. P. (2016). Estimation issues with PLS and CBSEM: where the bias lies!. Journal of Business Research, 69(10), 3998-4010.

Sekaran, U., \& Bougie, R. (2019). Research methods for business: A skill building approach. john Wiley \& sons.

Shanmugam, M., Sun, S., Amidi, A., Khani, F., \& Khani, F. (2016). The applications of social commerce constructs. International Journal of Information Management, 36(3), 425-432.

Shdaifat, A., Obeidallah, R., \& Ghazal, G. (2016). The impact and attitude toward social-media commerce within the Jordanian market. International Journal of Information Systems and Change Management, 8(4), 284-299.

Shin, D.-H. (2013). User experience in social commerce: In friends we trust. Behavior \& Information Technology, 32(1), 5267.

Shou, Y., Shan, S., Chen, A., Cheng, Y., \& Boer, H. (2020). Aspirations and environmental performance feedback: a behavioral perspective for green supply chain management. International Journal of Operations \& Production Management, 40(6), 729-751.

Xiang, Z., \& Gretzel, U. (2010). Role of social media in online travel information search. Tourism Management, 31(2), 179188.

Xu, C., Ryan, S., Prybutok, V., \& Wen, C. (2012). It is not for fun: An examination of social network site usage. Information \& Management, 49(5), 210-217.

Xu-Priour, D. L., Truong, Y., \& Klink, R. R. (2014). The effects of collectivism and polychronic time orientation on online social interaction and shopping behavior: A comparative study between China and France. Technological Forecasting and Social Change, 88, 265-275.

Yaseen, H., Dingley, K., \& Adams, C. (2016). Capturing the growth of e-commerce in Jordan using a novel research approach. International Journal of Management and Commerce Innovations, 3(2), 811-827.

Yoon, S. J. (2002). The antecedents and consequences of trust in online-purchase decisions. Journal of Interactive Marketing, 16(2), 47-63.

Zalloum, L., Alghadeer, H., \& Nusairat, N. (2019). The Effect of Using Mobile Banking Services Applications on Electronic Word of Mouth: The Mediating Role of Perceived Trust. International Business Research, 12(9), 62-80.

Zhou, L., Zhang, P., \& Zimmermann, H. D. (2013). Social commerce research: An integrated view. Electronic Commerce Research and Applications, 12(2), 61-68. 
(C) 2022 by the authors; licensee Growing Science, Canada. This is an open access article distributed under the terms and conditions of the Creative Commons Attribution (CC-BY) license (http://creativecommons.org/licenses/by/4.0/). 